\title{
Zoom ind på nærværet i denne C-tid
}

John Andreasen ${ }^{1}$, Institut for Kommunikation og Kultur - Dramaturgi, Aarhus Universitet

Jeg valgte at blive emeritus på Dramaturgi, få måneder før der viste sig at blive en COVID-19-nedlukning - efter mere end 40 år på Aarhus Universitet. Heldigvis for mig og heldigvis for mine studerende, som ved, at jeg nærmest er IT-analfabet. Jeg har brugt computer i undervisningen, men jeg har også bedt folk om at slukke deres æble-pc og mobiler for at løse nogle opgaver uden at søge alle svar på "nettet".

Corona-situationen fik mig til at tænke på min egen studietid på Institut for Nordisk sprog og litteratur i Århus i forrige århundrede, hvor computere endnu ikke fandtes, og undervisningen derfor var ganske "analog". Computeren og kontakt via den har bragt mange gode muligheder med sig, men pædagogisk sværger jeg grundlæggende til samvær face to face i samme rum.

På Nordisk havde jeg meget gavn og fornøjelse af at have en "dobbeltbevidsthed", når jeg selv blev undervist: Jeg hørte, hvad der blev sagt og tog stilling til det, men samtidig prøvede jeg ofte at lægge mærke til undervisernes kropssprog og måde at tale på. Det var jo deres basale virkemidler som pædagoger. Dét, der fik os med - eller fik os til at tænke på alt andet end undervisningen: deres vejrtrækning, deres pauseteknik, skandering af sætninger, mimik, gestik, blikke - henvendelser til forskellige dele af rummet eller ikke. Nogle var mest højreorienterede, andre kiggede mest til venstre i lokalet.

Da jeg mange år senere selv skulle give et mikrokursus i kropssprog for kolleger fra forskellige fakulteter, sluttede den sidste gang med følgende øjenåbner for flere: Til sidste opgave havde tre meldt sig til at forberede en gengivelse af en lille tekst. En efter en kom de ind og fremlagde den for os "studerende". Jeg havde instrueret "de studerende" i reaktioner på den kommende forelæser. Forud for den sidste blev forsamlingen bedt om at bakke maks. op om den kommende foredragsholder - uden at klappe eller sige bifaldende lyde. Vedkommende kom ind og gik i gang, men efter et minuts tid afbrød vedkommende sig selv, pegede på forsamlingen og råbte: "Jeg ved godt, hvad I er ude på!". Som en tragisk erkendelse - og måske alligevel lykkelig - opdagede vedkommende pludselig, at man som underviser bliver set på og vurderet konstant for alt, hvad man siger og gør. Like it or not. Den erkendelse kan bruges til egen fordel i stedet for at blive fortrængt eller ligefrem traumatisk.

Ironisk nok er det ikke bare undervisere, der kan være ubevidste om deres egen virkning. Rigtig mange studerende er desværre også ret uvidende om deres egen betydning for en succesfuld undervisning. Derfor har jeg nogle gange lagt op til en fælles ansvarsdiskussion ved at lave følgende treleddede øvelse med et hold. 1015 stykker melder sig frivilligt til et lille, muntert eksperiment, og de stiller sig på to rækker (A og B) overfor hinanden, mens resten placerer sig, så de kan se, hvad der foregår. I hver omgang må de studerende selv vælge, hvordan de vil udtrykke sig. Jeg tæller til 5, og så finder hver deltager en positur. A skal illustrere "rædselsholdet". Derefter skal B illustrere "yndlingsholdet". Til sidst skal alle illustrere "gennemsnitsholdet". Efter en del grin får

${ }^{1}$ Kontakt: draja@cc.au.dk 
vi som regel en god snak om, at jeg ved, de ser på mig, men at jeg også ser dem og deres (manglende) reaktioner. Tilsammen skaber vores reaktioner på hinanden en god eller mindre god læringssituation.

Fjernundervisning kan supplere, men ikke erstatte tilstedeværelsesundervisningen. Der foregår så meget $\mathrm{i}$ rummet, som ikke kan anvendes godt nok gennem Zoom, Teams eller Skype. Undervisning er give and take. Og mange misforståelser eller manglende forståelser kan bedre korrigeres, når man kan se og høre hinanden mere direkte og tydeligt. Vigtige nuancer i kommunikationen går let tabt mellem skærme, der kan så meget andet, som mange andre har meget mere forstand på, end jeg har.

\section{Betingelser for brug af denne artikel}

Denne artikel er omfattet af ophavsretsloven, og der må citeres fra den.

Følgende betingelser skal dog være opfyldt:

- Citatet skal være i overensstemmelse med "god skik"

- Der må kun citeres „i det omfang, som betinges af formålet"

- Ophavsmanden til teksten skal krediteres, og kilden skal angives ift. ovenstående bibliografiske oplysninger 